\title{
The Instructions of Melanesian Cargo Cults for the Asia-Pacific Future
}

\author{
GARRY WINSTON TROMPF \\ Departments of Studies in Religion and Peace and Conflict Studies, \\ Faculty of Arts and Social Sciences, University of Sydney.
}

\begin{abstract}
So-called cargo cults are new religious movements best known among the indigenous population of Oceania, especially Melanesia.Their focus of attention is the mystery surrounding the new goods brought by lightskinned strangers in awe-striking ocean-going vessels and (later) in great flying 'bird-like' containers. Various socio-religious movements arose in response to these European-style wares (later internationally-marketed commodities), or "the Cargo" (pidgin: Kago), often in agitated collective expectation of an extraordinary arrival of new riches. The Melanesian outbursts have been typically inspired by prophet-type leaders, with their messages reflectinga transition between indigenous traditions and more settled islander Christianities. This paper moves on from describing and explaining southwest Pacific cargo-type movements to the issue of the ethos out of which they arose, and addresses the sociology of hope for Cargo(or modern commodities in plenty) as a global issue, best described as "Cargoism." Sets of beliefs in the coming bounty and changing power of Cargo have much more than 'provincial' or local-indigenous implications. They point to a worldwide plethora of expectations wherein material items define the essential comforts of life and capture the individual, family and collective imaginations about the preferred human future. Exploring some of the 'universally human' implications within the logic of cargo-cult thinking in its Pacific context, this paper introduces Cargoism as a transoceanic and intercontinental issue that has enormous environmental and politicoeconomic ramifications. Presages of environmental stress lie with globalizing cargoist dreams and pressures, including hopes for progress and technological solutions offered by trade and commercial expansions (proffered by powerful nations, including China, for the Asia-Pacific future).
\end{abstract}

\author{
Article History \\ Received: 02 August \\ 2021 \\ Accepted: 15 November \\ 2021
}

\section{Keywords}

Belt and Road Initiative;

Cargo Cults;

Cargoism;

Commodification;

Environmentalism;

Millennialism;

New Religious

Movements;

Religion;

Sociology of Religion;

Social Movements;

Technology.

CONTACT Garry Winston Trompf $\$ garry.trompf@sydney.edu.au 9 Departments of Studies in Religion and Peace and Conflict Studies, Faculty of Arts and Social Sciences, University of Sydney.

\section{(c) (i)}

(C) 2021 The Author(s). Published by Enviro Research Publishers.

This is an $\partial$ Open Access article licensed under a Creative Commons license: Attribution 4.0 International (CC-BY).

Doi: $10.12944 / C R J S S H .4 .2 .01$ 


\section{'Cargo Cults'}

This contribution concerns intriguing new socioreligious movements named 'Cargo Cults.' They have mainly emerged from Melanesia over the last century and more, Melanesia being the complex of 'Black Islands' in the Pacific Ocean, from Vokelkop at the western end of the great New Guinea island (now part of Indonesia) across to western Fiji. This huge Oceanic region holds nearly a quarter of the planet's discrete languages and religio-cultural forms. From the end of the nineteenth century, it was reported that Melanesian islanders made unusual responses to the arrival of entirely new and mysterious goods on their shores. Products of the European Industrial Revolution, transferred to farthest-off imperial holdings, were being endowed by the indigenes with religious significance, and this article first seeks to understand these movements in the context of colonialism and sudden social change and then goes on to consider 'instructive lessons' of such phenomena for current humanity, maintaining that we are all affected by hopes and dreams to possess 'Cargo,' or items of new technology, that fulfil our lives and yet present environmental problems.

\section{Materials and Methods}

This article combines disciplines in the Social Sciences and Humanities. It relies extensively on the author's fieldwork on so-called cargo cults in all regions of Melanesia from 1973 until the present time and on the mass of ethnographic, sociological and historical data about them. The article moves from a social scientific mode, in a summary description and general sociological analysis of them, to an estimate, more in the humanities mode, drawing on general philosophical, axiological and ethicoenvironmentalist insights, of what these striking phenomena teach us about the nature of being human and our susceptibility to material desires that can be played upon by political forces.

\section{'Cargo Cults'}

When outsiders first saw ritual actions performed to procure Cargo from 'supernatural' sources, their reports of them were rather bland, such indigenous collective reactions being simply categorized by 'colonial' anthropologists in British New Guinea (Papua) as "new religious cults"1 and by missionaries to German Neuguinea as Schwärmgeister ("dreamers"). ${ }^{2}$ With Anthropology early as the dominant social science for studying
Melanesia, initially inadequate descriptors, such as collective "Madness" (by Francis Williams in 1923), gave way to less depreciative classifications, though the phrase 'cargo cult,' an alliteration not without irony in tone, stuck as the popular usage from the 1940s. In anthropological studies cargo cults were inter alia viewed as a species of nativism (by Ralph Linton in 1943), ${ }^{3}$ prophetism (Andreas Lommel, 1951), revitalization (Anthony Wallace, 1956), messianism (Vittorio Lanternari, 1963), and crisis cult (Weston La Barre, 1971). ${ }^{4}$ Most recently cargo cults have been put among the "material religions"; while anthropologically informed missiologists started reading such strong group hopes for sudden new material blessings as "salvation movements." Sociologists were to put in their oars. Notable among them for penning the first general history and survey of cargo cults, British neo-Marxist Peter Worsley took them as expressions of revolutionary millenarianism (and of pre-political anti-colonial protest activity), ${ }^{6}$ and not long after Israeli sociologist Yonina Talmon famously classified them among millenarian movements. Since then, in the sociology of religion, voices have been more cautious about the varying degrees of hopeful expectations in "cargo movements,"' and whether the coming of the Kago should always be reckoned a 'millennium'-like event. ${ }^{8}$

The key feature of 'classic' cargo cult activity, especially between 1920 and 1980, has been the excited collective preparation within or across villages for the arrival of the new goods in plenty. By way of ritual mimicry of the dominating foreigners' behavior, basic wharves were set up if the riches were to come by sea, or, if by air, landing strips were cleared, even wooden airplanes constructed. Imitation wireless aerials were erected, and tables were made on the beaches with lookalikes to the whites' cutlery. Sometimes property and livestock were destroyed as a display of sacrificial commitment that the spirit world would yield its benison. In more traditional modes, the ancestors are typically the near-coming bearers of riches, while where mission apocalyptic teaching has captured the imagination, Jesus will come again with the returning dead, ready to share heavenly treasures. ${ }^{9}$

Of ethnohistorical importance is the continuity between trust invested in traditional rituals to bring material increase and the new hopes in colonial 
times. In pre-contact life, as established by oralhistorical research, experimental ritual procedures had been grafted on to long-inured practices, typically as a result of someone's dream-visions; and so 'prosperity cults' had arisen, as innovative collective impetuses under new (if often temporary) leadership. ${ }^{10}$ These adaptations, if welcomed as promising responses to adverse environmental or circumstantial pressures, confirm that islander traditions were pragmatic and not as static as supposed. There was readiness to experiment and acquire new objects and techniques for securing greater fecundity, better material outcomes signaling full "Life," welcome "Excess," and good relations in "the community of both the living and the dead".11 The urge to acquire the startling new Kago, however, presented a real ritual challenge. Wealth was traditionally assured through reciprocal relations between human groups conceding cooperation, and between humans and those spirits who responded beneficently to sacrificial gifts. The trouble with the Cargo was that it remained at first largely the preserve of newcomers, who increasingly became the colonial masters, and who presented the promise of good change but exasperatingly only distributed their marvellous possessions or reciprocated with them in very limited ways. ${ }^{12}$ If Christian worship was seen as a "road to the Cargo," one seemed to "pray, pray, pray" without tangibles in the hand. ${ }^{13}$

'Cargo cults' turn out to be movements of "cultural resistance" to rectify what appears both customarily wrong (failed reciprocity) and a sudden, apocalypselike cosmic faltering when the indigenes' 'stoneage' order of things jolted to an $\mathrm{e}^{14}$ The cults' first expressions had limited goals-stashes of steel axes and guns, supplied tins of 'bully beef'-but through dreams of hidden "treasure" (koreri, as it was called in West Papua under Islamic influence) they often entailed grander anticipations of Cargo for all. Koreri agitants expected great benison from the invading Japanese (1941), but when they came up against oppression they organized an army in the name of America, expecting complete protection from their ancestors against Japanese bullets but dying in hundreds. ${ }^{15}$ Once the Japanese reached Guadalcanal (Solomon Islands), the Allied Forces converged in dramatic reaction, bringing wartime experiences to locals of unforeseen marvels, with huge warships disgorging extraordinary quantities of military cargoes and large numbers of newly present African-American black soldiers marching and operating beside the whites. Tons of leftover goods presaged plenty to come. ${ }^{16}$ African Americans brought impetuses to protest and organize for separate self-rule over local affairs (as on the central Solomons), ${ }^{17}$ even to create imitation GI forces and barracks (on Tanna Island, New Hebrides/ Vanuatu). ${ }^{18}$ In various cultural pockets, money was in sudden circulation, as if had could be made by magic.Large, even trans-regional indigenous movements emerged in response, with prophetic (often recognizably charismatic) leaders sometimes foretelling environal catastrophes before the Cargo arrival. A refusal to be inferiorized by lack of Cargo combines with a will to have the Power behind the Cargo urgently. ${ }^{19}$ Once the call to engage in an altercation and the predicted time of transformation have passed, and if the agitating group survives both colonial reactions to quell trouble-making and the cognitive dissonance of an apparently failed prophecy, the newborn movements routinize their quests into weekly practices (often to multiply money by experimental magico-ritual techniques) as new social identities. ${ }^{20}$

Generally these responses and urges of disaffection, even reprisal, if they have endurance, present as new religious movements, with each specifically capable of special actions-non-cooperation with missions or colonial officials, anti-tax activity, alternative 'micro-nationalist government', ${ }^{21}$ and in various cases outlandish independent churches to compete with major denominations. ${ }^{22}$ The widespread movement founded by Yali Singini in coastal New Guinea's Madang area (from 1945) involved all these hallmarks, together with formalized myth-histories to legitimize it and rituals, bizarrely with the use of Yali's semen in bottles, set on altars, to bring on money and new acquisitions. ${ }^{23}$ In the hinterland east Sepik, local apocalyptic figure Mattias Yaliwan claimed (in 1971) that traditional stable prosperity would return once American geodesic markers were removed from the summit of Mount Huru[n] (east of the Sepik River) and Kago would also burst from an ancestral cornucopia from the summit. His managerial sidekick Daniel Hawina organized a new cult house for multiplying money (coins splashed by naked nubile women at night with young men holding them from behind in a suggestion of 'total fertility'), and he founded the Sepik-regional Peli ('Hawk') Association.Given 
Yaliwan's prophecy, Hawina organized a piece-bypiece dismantling of the markers passed one-by-one by a long line of hopefuls down the mountainside. ${ }^{24}$ Other cases, of much interest to Marxist Worsley, were the 'pre-political' agitations of Paliau Maloat, who set up New Guinea's first local government as well as an independent church, on the Manus island group. ${ }^{25}$ Another move to resist Australian-colonial head tax, backed up by a 'baby garden' to create a 'master race,' was led by John Teosin and his Hahalis Welfare Society for the ultra-black Buka islanders, off north Bougainville. ${ }^{26}$

Most cargo-type activities dissipated quickly, whether through local disillusionment or a patrol officer's rousing. But after some Melanesian island groups secured political independence (1970-80, the biggest being Papua New Guinea [PNG] in 1975), those movements that had achieved the largest followings (Yali's 'Work,' Peli, Paliau's Baluan church, Hahalis) continued on to this day despite their leaders' deaths, because they developed promising-looking weekly rituals. Some campaigned to draw votes to gain political clout. At the turn of the millennium, Francis Koimanrea had progressed to become Governor of the PNG's East New Britain Province, and yet was a follower of Koriam's Law (Lo), which taught that through the right garden practices, generosity in a cooperative society, and keeping the Ten Commandments, the soon-to-return ancestors would bring extraordinary riches, even create a great city around Jacquinot Bay by a mere wish. ${ }^{27}$ Fed by high dreaming, organizational persistence, week-by-week labor and generosity were spent on the cultic cause, and as the leader Dakoa (on tiny Unea island way out in the Bismarck Sea) stressedof his "church,"the committed group's "love and its money will draw the dead closer", ${ }^{28}$ and the author was shown by Dakoa the secret cult object, a carved snake around a pole, possibly from an old masthead of a foreign ship, evoking both traditional vitality and success in new business (pidg: bisnis). In contrast, on Espiritu Santo (to the north of near-independent Vanuatu), the secession movement led by Jimmy Stevens collapsed because he put his trust in unreliable outside interests, including America's 'tax-havenseeking' Phoenix Foundation, and the promise that 100,000 Vietnamese workers would arrive on the island to do all the new-style stock-farming and development work. ${ }^{29}$
We would be unfair to limit the number of new religious movements in Melanesia to those intensely focused on Cargo, because some would be better described as protest, reformist, cooperativist, spiritistic, or just plain apocalyptic, ${ }^{30}$ while of special interest to anthropologists would be various increase, prosperity and fertility cults that can be documented as sprouting up in near-contact times. ${ }^{31}$ We do not want to exaggerate the extent of discrete movements and of negative reactions to change, in any case, when the history of the remarkable indigenous embracing of the Christian message(s) in the western Pacific is overall one without many serious altercations, even if 'materialist hopes' of one kind or another have affected conversion rates.Intriguingly, instances of the kind of activities we have concentrated on up to now were few and far between in wider Oceania. Admittedly, concern to acquire new goods in Micronesia and Polynesia showed up in early contact times with raids upon passing ships. In the more hierarchized societies of these widely dispersed regions, however, hopes were placed in chiefs, indeed monarchs (notably in Tonga and Hawai'i), as representatives of the gods who could ensure prosperity for the islands and tribes they controlled. And they were the ones expected to negotiate, sometimes in high formality, with outsiders. In less structured contexts outside Melanesia, admittedly, cargo-cult phenomena have manifested, as when on Rennell Island (a Polynesian enclave in the Solomons), the chiefly prophet Teghata sent messengers up to heaven to bring down calicos for his followers (in 1936). And with their more tiered cosmos and society, please note, the Polynesian tendency has been more to look skywards for the Cargo rather than horizontally ('from a distance') as with Melanesians. ${ }^{32}$ Yet quite apart from these relativities in Pacific Island new religious energies, and asidefrom the question as to whether we might identify related phenomena of tense expectancy right across world cultures, the Melanesian data have certainly put cargo cults on the map.

Many questions open up about the multiple implications of cargo cultism, some already on the table, as to whether they should be placed under a separate social-scientific or socio-religious category, or within 'millenarianism'33 or within quests for a returned paradise or the Golden Age, ${ }^{34}$ 
and as to whether they are irrational or perfectly logical according to traditionally preconceived Weltanschauungen, ${ }^{35}$ and how they might illustrate theories of marginalization, relative deprivation, high-pressure collective hope, failed prophecy, and so on. ${ }^{36}$ Already we see 'cargo cult' lends itself to a certain 'universalization' of discussion around it. In what follows I will be taking a didactic (though not moralistic approach) approach, in asking what is instructive, what serves as a lesson, from cargo cultist agitations, most broadly as disclosing something about our humanity, but in the end more particularly as to how these activities prepare intelligent readers and actors for mentalités in the Pacific, at a time when global powers have their visions for the grand future of theAsia-Pacific region.

\section{Cargoism}

The specificity of collective action and ritual to prepare for the dramatic appearance of Kago does not lend itself to universalizing discussion so much as the idea and hope of acquiring new-style goods. But 'cargo cult,' as abstracted, carries its own arresting force, a kind of Gestalt of both desire and extravagance, addressing everyone's arena of want, satisfaction, betterment, and a bright (if not utterly bountiful) future. There is a shock value in it. Can the human expression of religiosity ever be so blatantly materialistic as it appears to be in the cargo cult? and does it not betray a certain naïve honesty? Obviously what is very universal is the concern for and possible possession of manufactured (nowadays commonly sold mass-produced) objects of necessity, ease, or prestige. That would be utterly bland were it not for the mounting psychological and very widely felt existential pressures that life would be quite unacceptable, exasperating unsatisfying, without a given amount of such widely transported 'cargo-items.' Such thinking and hoping, now rising to be global in proportion, stretches beyond the 'phenomenology of cult' and combines in strong feelings we here name and introduce as Cargo-ism.

The concept of "cargoism" seems first introduced into social-scientific literature by the American anthropologist Thomas Harding (in 1967), who took cargo cults to be a function of prevalent beliefs about the eruptive coming of "European cargo." 37 In the context of rapid social change, these intense "cargoistic" hopes were often translated as group aspirations for ultra-quick development in the
Melanesian political sphere ${ }^{38}$ In time, cargoism was used to denote an ethos, as when West Papua scholar Benny Giay used Kargoisme to cover both distinctive cargo movements and the prevalence of very high material expectations from following both the churches' social improvement programs and national infrastructural interventions. ${ }^{39}$ By the 1990s the present author was conceptualizing 'cargoism' as a mentalité-a cluster of ideas, ideals, hopes, sought-for goals and preparations-that could be assessed cross-culturally, and he started with comparisons between western Pacific cargoism and socio-oneiric components of the so-called 'American dream,' especially unrealistic and sometimes culticlooking activity to bring on financial success. ${ }^{40}$

The United States is of particular interest in this context because it has recently come under critical scrutiny for the way traditional religio-patriotic commitments to the nation as elect, special, exceptional, technologically most advanced, and with greatness among the nations, has bred an "enchantment" (or- or mis enchantment) with "Mammon," and allowed capitalism to be less a restrainable outgrowth of religious energies than the virtual "successor to [the Christian] faith". ${ }^{41}$ But of course the 'cargoistic profile' is hardly to be confined to the socially constructed USA as a "land of hope and glory," but can now be filled out in terms of a contemporary cosmopolitan or globalizing conceptual set of expectations about quickly gained worldly comfort the world round. Indeed, the other great 'super power,' the People's Republic of China, hardly stays out of the picture. This is not only considering that the USA has been saturated with Chinese smaller products (or cargoes), that remain globally attractive as well, but because the PRC has fostered a version of Socialism that suits her peoples' propensities for marketeering, and their materialist hope for family success not so different from American 'cargo dreaming'. ${ }^{42}$

At base, the Melanesian cargo cult can be instructive because it so arrestingly exposes a crucial current issue for humans on earth (in the "Anthropocene"): that is, what to draw hope from and what to do with the extraordinary array of the "new goods" in human history, available from the 1880 s or the so-called Second Industrial Revolution onwards. ${ }^{43}$ And we consider cargoism as a related "framework concept" that covers the obvious plethora of facts (very easily 
established empirically) that people need or want mass-produced non-traditional goods, and their hopes for, feeling about, and will to acquire them have become a huge "domain" of "non-scholarly" social communication in an "incessant chattering". ${ }^{4}$ To clarify, we can distinguish cargoism from "commodity fetishism" in Karl Marx's classic vocabulary, because this famously refers to workers' obsequious 'bowing down' to objects in their manufacturing process, as organized by the bosses. ${ }^{45} \mathrm{At}$ the same time to notice the religious or spiritual implication of new industrial products is hardly unhelpful. Again, cargoism cannot be equated with consumerism in any simple way, or with habitus as the reproduction of ingrained attitudes, including mental habits or schemes of perception, appreciation, feeling, and active response; ${ }^{46}$ although there is overlap and the recognition of being 'taken in or locked in' (from certain axiological view points even 'blinded' or 'duped') is useful. Cargoism is a wilfully wishing mode, and its presence has been universalizing, certainly beyond developed 'consumer societies,' or 'the acquisitive society' in a still more general sense. ${ }^{47}$ And while not underestimating the importance of new "cultural productions" on and through religion, and the inexorable influences of modernity here, there and everywhere (starting from circulated promotions and symbolized by the 1970s magazine advertisement that has of Coca Cola and Volkswagen at the North Pole), our concentration is on Cargo above all as marvel and 'salvifically potent'- as an answer to a lack or loss of wellbeing. We need to go back to basics, indeed to Melanesia,

Cargo cult phenomena are so arresting because of the special context and timing: they emerge out an encounter between many lithic ('stone-age') cultures and modern humans at the latter's highest point of technological achievements, including the capacity to fly, let alone use the by-now widely accessible commercial generation of electricity (from 1882), trans-oceanic telephone connections (from 1927), or refrigerators independent of the ice-man (by 1940). Of course gaining cargo items had simple beginnings around the 'black islands': whether by theft, trade or early employment, individual metals tools and pots filtered in. Their first (typically male) possessors (as in the Wahgi Valley, New Guinea highlands in 1935) would find a queue of people with foodstuffs outside their wives' houses wanting to try out the new thing. ${ }^{48}$ In those circumstances newcomers would make sure they had a much greater supply of traditional (usually shell) money for purchasing food, and they dominated guns, so it would not be surprising that early attempts at magical production were for a mixture of traditional and introduced-manufactured items, especially firearms for easy hunting ${ }^{49}$ But the Melanesian world was to be witness to untold wonders, from trousers to toilet paper, from wood-and-steel wheel-based vehicles to fiber-glass canoes, from tin to plastic buckets, and so on. When we are left "wondering about wonder," it would not come as surprise that news about the newly received objects spread like wildfire across tribal boundaries along trade routes, independently of anybody seeing any items, though some token-some powerful non-verbal communication of inexpressible materialities_might be used (a cow's hair in a famous highland Enga case) to herald their preternatural appearance and their mysterious owners' fitting control over "giant pigs".50 Then begins the story of "cargo proper", ${ }^{51}$ when novel items were more frequently sighted, with more and more in widening 'informetric' bursts of witness and increased accessibility, that is, depending, in the deep jungle and difficult terrain in Melanesia, on where a given people is located, whether blessed with closeness to a town or new roadworks, or virtually forbidden by territorial circumstance.

In time, a sense of expected repetition developed empirically. A persistence of sighted arrivals of sea-vessels and planes from over or above the horizon, the sense of anticipation about another 'big happening' to come, was to settle; and whether one was called to participate at an arrival or just watches on, even from a distance, the tensions surrounding a docking or landing, and the hustle and bustle of unloading cargoes, would shift from being early feelings of nervousness to a 'new norm.' In general terms this is the imagined yet never-to-be fully documented journey from the time grown men fainted at seeing barely believable sights, touches and sounds of the strangest things, through new experiences of deploying what was most useful among them in the village, down the occasional opportunities to view a whole range of purchasable packaged goods in a store, and on to shared rumors about where all these prodigies came from, when no one could report on the production lines of a factory (which many of us around the globe never get to 
see anyway). Many of the objects seemed basically the same over time, but the known and nameable foreigners who controlled them would come and go. When the World War hit, the quantity and dramatic movement surrounding the Cargo magnified, as did the rumors that spread to untouched places and the frustration felt by those living far away from the new possibilities. $^{52}$

The mystery(pidgin: kru) of the goods, always monopolized by recognizable groups (colonial or government officials, planters, missionaries and intruding militia), seriously demanded explanation. Perhaps it is too easy to laugh at the attempts to make meaning of it all. We can see the attraction in doughty individuals who claimed to hold 'the key' and generated the cargo cults we quickly surveyed (indeed Yaliwan's impetus to 'start something' came when, laboring as a gardener on mission grounds in 1962, he picked up an isolated cross-shaped key from the grass only to get in trouble for it by a Catholic priest, and knew he was on to 'the secret'). When literacy increased through mission schools, expectedly, labels on the cargoes could be read. In the 1930s a Jaua man (coastal and northern Papua) read his own clan's name Soap on boxes marked SOAP at the Gona wharf and 'knew' the outsiders were tricking his people, diverting gifts away from the rightful recipients that were really gifts from Jaua ancestors to boot. Such incidents and disclosures made for suspicion and resentment. Melanesians were constantly involved in the reciprocities of giveand-take, under sacred obligations to be involved in exchanges that often led on to great feasts, never expecting something for nothing: but the whites just kept too many enticing things to themselves and displayed only unreciprocal condescension. ${ }^{53}$

Quite apart from any cults or movements congealing, the most widespread shared grassroots issue for Melanesians - the heated topic for discussion-has been the Cargo, its hidden indications (pidgin: tok i hait), its translated and transformed "significations," its out-of-place extra ordinariness, and in the course of time the increased colorof its packaged presentations. And there was the surpassing power of modern money over old exchange valuables; money was steadily recognized as a road to the Cargo, but always such a hard road that it was tempting to believe needed the accompaniments of magic or miracle. We simply have to recognize the datum of radical new possibilities already inhering in the incoming chattels, gadgets and machines. Right from the start of their infiltrations, incipiently, they were pregnant with eschatological-looking functions, in that they were bringing to an end an age-old order of daily struggle. ${ }^{54}$ (cf. Keck 1982). Even if un- or just-contacted Melanesians had no conception of some prolonged Stone Age, they soon realized in the flashes of cargo before their inexperienced eyes that drastic alterations were descending on their lifeways. But something was awry. The arrangement of things (the 'system,' as most of it would pinpoint it) was always militating against easy access, and in any case too much success brought its own dangers, including jealousies that might breed dreaded sorcery. In the most recent times huge mining projects offered employment; in the end so much was expropriated away with too little coming the indigenes' way.

To epitomize, ponder an intriguing 2003 encounter between a bright young American anthropologist Eben Kirksey, concerned about the fate of West Papua (as part of Indonesia), and a highland Yali tribesman Silas Kiwak, now a Protestant elder, in West Papua's great Baliem Valley (where primitiveness allegedly lasts longest on earth). They met near a highland airstrip, and because the young man showed concern for West Papua's future, Kiwak told him a story. "In the beginning," he averred, "the ancestors of the first whites and the first blacks played soccer together ... here on a landing strip. All sorts of machines were freely available. We had airplanes, radios, and electric generators. Everybody had shoes, soccer balls, outhouses, and rice." But one day, he went on, there occurred an act of deceit, one apparently reinforced in Kiwak's mind by known problems under the Dutch colonial administration of what was then Netherlands NieuwGuinea (1828-1963):

The whites told the blacks to gather together on the soccer field. Our ancestors, the blacks, were told to shut their eyes, and pray. They complied. As the prayer was finishing one of the black men opened his eyes. He saw the last white person disappearing down a hole in the earth. This black man shouted out. All the goods had vanished. Everyone assembled on the field opened their eyes and witnessed the promise of the last departing white man. The last 
white said he would return one day with the goods. Then he entered the hole, and it closed behind him. ${ }^{55}$

Already we can detect in this story, indeed in our whole account thus far, a typical vulnerability of small peoples in the complicated, bullet-headed world of modern politics, in the West Papuan case of neo-colonial Indonesian expansionism, and of transnational mining and business interests needed by states, through foreign investment, to prop up their comparatively weak coffers in a arena of political changeability, with each national government wanting to hold power and prove that they have not 'failed.' The cry of the West Papuan storyteller, Kirksey wants to say, is one in which the goalposts of being participant in the marvels of development have been removed. The promise of wellbeing, signified by Cargo, is still being swallowed into the ground, or gouged out of it, Kirksey argues, in immediately thinking of Grasberg, the biggest gold-silver-and-copper mine on earth, worked by Freeport McMoRan and Rio Tinto. But the promise and hopes of the Cargosomehow still seizes the soul. Elsewhere in the region, cargoist discourse, as a home-grown warrant for equitably distributed and reciprocally controlled riches, can still say something striking to those corrupt and unruly governments that overlook general fairness, apply excessive coercion, and always leave the little dreamers of overall, evenhanded improvements badly short-changed. That is a lesson, not just for Melanesia, not even for the future of the Asia-Pacific, but for fragile human and inter-group relationships worldwide.

At this point, we could muse that Melanesians in their puzzlement over the Cargo are like 'everyman' trying to make sense of massive technological change and its impact on the global environment. We cannot deny, though, Melanesian countries have been dragged kicking and screaming into the twenty-first century. Across the range of them there are of course elite minorities dressed in expensive suits, drawing out-of-proportion salaries, driving large SUVs, and cluttering their large houses with consumer goods after making their way to emporia and hardware stories. Success comes with university degrees or administrative diplomas. Even though the personnel of the churches generally do not carry the same taint ofriches, on the greater New Guinea island they run the safest tertiary institutions, and across Melanesia many impressive schools, for that reason being financially rewarded as offering highquality services. Local theologians seem to find it threatening that the new goods are not part of God's Creation, when a good case might be made that they are naked emblems of human over-reaching, of the new world market process now being "God", 56 or of "men becoming the gods" (in Nietzchean terms) with the skill to pollute and possibly blow up everything. ${ }^{57}$ Those Melanesians who live and breathe within the ambience, the ready availability of the Cargo, cannot escape the same complex of aspirations and cluster of feelings shared by those in the same position around the globe. They cannot imagine what life would be like without a refrigerator, a stove, a television, a mobile phone (though even the humblest villagers seek to hold the latter in their hands, and through the islands one finds electrical 'top-up' shops can now make better bisnis than those selling coca cola in the tropical heat!) And any criticism from the outside that they should not overdo their acquisition and consumption will appear like utter hypocrisy.

Yes, Cargoism eventually expresses itself as a more complete "modernity", a "materializing" of nations, ${ }^{58}$ whereby it is expected of those who help run an independent nation (or near-autonomous province) should set the tone of "development." A country's success stories set the template and example to those back in the village so that they can leave their cultural and socio-economic inferiority behind, thatched roofs for corrugated iron, the strenuous hunting of wallaby for tinned mackerel, sails and paddles for outboard motors, outdoor markets for shops. In the end the model almost inevitably involves the welcoming of investments in industries that bring national wealth, with outcomes, already showing up in the Asia-Pacific, that powerful nations have been looking for opportunities at the extremities of the earth, to extend the international market place and their chances to compete for economic influence. Under such pressures matters can easily go awry. Even in running democratic states, Pacific Islanders are less experienced and vulnerable visà-vis technicalities of high-level deals, and new indigenous leaders can often be less aware of the common good than serving their own group, their own ambitions and their own purse. ${ }^{59}$ Already there has been modern civil wars in Melanesia (one over the world's third largest copper mine, on Bougainville) and it is not as if, pace the plethora 
of less belligerent cargo cults, there have not been fierce insurrectionary outbursts and armed liberation movements in the region. ${ }^{60}$ As the future of the Pacific unfolds, and plans for the Asia-Pacific mature, big international players, especially the United States, China, Australia, and France, have to be sensitized to the issues raised in this paper. This will include what is now the world-wide dilemma of Cargoism, that everyone is potentially not going to feel right about themselves, and not experience sufficient well being, if they lack a certain number of manufactured items, preferably located for the majority in a concretized apartment, and with a good deal of plastic and rubber around soon to go to waste. As this author dared to pronounce at the Fourth International Conference for the Environmental Future (Budapest 1990), Cargoism, in its rampant rise out of the sad ashes or decline of traditional societies, is indeed the biggest threat to humanity's environmental future, ${ }^{61}$ and this is the cargo cult's most salient lesson for the Asia-Pacific future.

The People's Republic of China, rising as "the World Factory in the global economy", ${ }^{62}$ and fast replacing Taiwan in the continuing Chinese impact on Oceania, ${ }^{63}$ has various attractions for Pacific Islanders, including technology (learnt from Nanhai) to handle drowning islands at this crucial point in planetary eco-history, but above all in the production of cheap household items. The Belt and Road Initiative to the east thus carries some prospect of success. So far twelve Pacific political entities are involved, from west to east:

\section{Table 1: Pacific Island Involvement in PRF China's Belt and Road Initiative (at 2021)}

\begin{tabular}{lc}
\hline Indonesia (colonies: Papua \& West Papua) & New Zealand \\
Federated States of Micronesia** & Fiji (\& Tuvalu) \\
Papua New Guinea & Tonga \\
Solomon Islands & Samoa \\
New Caledonia*** & Niue ${ }^{* *}$ \\
Vanuatu & Cook Islands $^{* *}$ \\
Kiribati & French Polynesia*** $^{*}$ \\
& ${ }^{*}$ Both Papuas are barely autonomous Provinces of Indonesia \\
& $*$ Under special protection dependence \\
&
\end{tabular}

In this context of the anthropocene, however, new involvement in the Pacific demands awesome responsibility, with stresses on the Pacific Ocean approaching a tipping point. Revisionist Marxist theory, that environmentally irresponsible development and industrialization are counter to Socialist ideals, ${ }^{65}$ (e.g., Dachun 2017, 2018; Wendling 2009), will help internally as international voices of conscience hopefully can externally. With rising suspicions in the Islamic world about PRC's handling of Muslim minorities, on the other hand, the new Silk Road initiative to China's west, if it is to succeed in Central Asia, will most likely have increasingly negative responses. I will only succeed until preferred internal solutions are found to handle religious impetuses that will never go away in human societies, China included, and for which sources in earliest Marxism, and the history of religionaccommodating Marxismcan be used to make for the most extraordinary multifaceted national unity on earth. ${ }^{66}$ (Trompf 2019b).

\section{Results \& Discussion}

Cargo cultism and cargoism provide compelling instructions from a particular culture area about globalized hope for the 'good life' shared across myriad cultures, and also lessons about the human being's (potential) propensity to hope for too much too quickly, unthinkingly or too self-interestedly in desire for profit. Already 'cargo cult economics' and 'cargo cult politics' has entered journalese or political rhetoric to denote collective over-expectation (or playing on it as a 'carrot-on-a-stick' tactic). The deployment of the terminology for the self-realization 
and "conscienization" of humans, rather than the depreciation of unusual behaviour as a cultural laughing-stock, should be a priority for researchers. ${ }^{67}$

The culture area, the southwest Pacific that bequeaths us the relevant phenomena, houses peoples still vulnerable to persuasions and manipulations of those offering material enticements and national and local levels. Entry into the modern world seems inevitable for all traditional peoples, yet it should be publicized as a travesty by social science and humanities researchers that the Pacific Islands become a plaything of outside nations' economic expansionism and powerful moves for development advantages by multinational companies servicing the markets of hegemonic states. ${ }^{68}$ Besides, cargo cultism (in the form of distinctive movements) has dissipated, and while Cargoism is highly prevalent in the Pacific, in our framing of it is now a globalized factor in world social, health and environmental issues.

In light of what actually happens on the ground to 'feed' Cargoism, it should be incumbent upon the nations and their policy-makers to work towards international agreements to put limits on the production of unnecessary or 'surplus' commodity items that threaten our environmental future, many of these, interestingly, not necessarily being 'luxury' items (though attention to inequities in the political economy of marketing luxuries also demands checking). Let the special image of the Cargo dream have its effect, not to dupe but instruct for betterment.

\section{Acknowledgements}

The author carried out the research work and findings on his/her own without any external help.

\section{Funding}

A much shorter version of this paper was presented at the First International Conference on Asia Pacific, University of Yunnan, Kunming, PR China, on 21-24 May 2019, and was partly funded by the School of Ethnology and Anthropology there.

\section{Conflict of interest}

There is no conflict of interest.

\section{References}

1. Allen, B. (1976) 'Information Flow and Innovation: Diffusion in the East Sepik District, Papua New Guinea' (PhD diss., ANU). Canberra: ANU.

2. Ayius, A., \& May, R. J. (Eds.). (2007) Corruption in Papua New Guinea: Towards an Understanding of Issues. Port Moresby: National Research Institute.

3. Barr, J., \&Trompf. G. W. (1983) "Independent Churches and Recent Ecstatic Phenomena in Melanesia." Oceania, 54(1), 48-132; (2), 122-132.

4. Bourdieu, P., \&Passeron, J.-C.. ([1977] 1990) Reproduction in Education, Society and Culture (trans. R. Nice). London: Sage.

5. Burridge, K. O. L. (1969)New Heaven, New Earth: A Study of Millenarian Activities. Oxford: Basil Blackwell.

6. Chinnery, P., \& Haddon, A.(1917) "Five New Religious Cults". Hibbert Journal, 15(3), 448463.

7. Chow, P. (2010) "China as the World Market and/ or the World Factory in the Global Economy". In Y. Chuang and S. Thomas (Eds.), China and the
World Economy: China's Economic Rise after Three Decades of Reform (Berliner China-Hefte 37) (pp. 39-63). Berlin: LIT.

8. Christiansen, P. (1969) The Melanesian Cargo Cult: Millenarianism as a Factor in Cultural Change (trans. John Gosney). Copenhagen: Akademisk Forlag.

9. Cox, H. (2016) The Market as God. Cambridge, MA: Harvard University Press.

10. Crocombe, R. (2007) "The Fourth Wave: Chinese in the Pacific Islands in the TwentyFirst Century". CSCSD Occasional Paper [no. 1], 23-34.

11. Dachun, L. (2017) Shen du: Ma ke si ke xue ji shu guan yu dang dai ke ji shu lun yan jiu [Reconsiderations: A Study on Marx's View and Contemporary Thoughts of Science and Technology] (Library of Marxism Studies 2). Beijing; China Renmin University Press.

12. Dachun, L. (2018) "The Study of Marx's Science and Technology Theory and its Significance". Teaching and Research (Beijing), 52 (4), 28-35.

13. Descroches, H. (1973) Sociologie de 
l'espérance. Paris, Calmann-Lévy.

14. Eliade, M. (1965) The Two and the One (trans. John Cohen). London: Harvill.

15. Foster, R. (2002) Materializing the Nation: Commodities, Consumption, and Media in Papua New Guinea. Bloomington: Indiana University Press.

16. Freire, P. (1972) Pedagogy of the Oppressed (trans. M. B. Ramos). Harmondsworth: Penguin.

17. Fugmann, G. (1977) "Salvation Expressed in a Melanesian Contexts". Point, (1), 122-133.

18. Gesch, P. (1985). Initiative and Initiation: $A$ Cargo-type Movement in the Sepik against its Background in Traditional Village Religion (Studia Instituti Anthropos 33). St Augustin: Anthropos.

19. Gesch, P. (1990) "The Cultivation of Surprise and Excess: The Encounter of Cultures in the Sepik of Papua New Guinea". In G. W. Trompf (Ed.), Cargo Cults and Millenarian Movements (Religion and Society 29) (pp. 213-36). Berlin: Mouton de Gruyter.

20. Gesch, P. (2008) "Cultural Resistance Movements in Papua New Guinea". In G. W. Trompf (Ed.), Melanesian Religion and Christianity (pp. 82-100). Goroka: Melanesian Institute.

21. Giay, B. (1986) Kargoisme di Irian Jaya. Sentani: Region.

22. Harding T. and Lawrence, P. (1971) "Cash Crops or Cargo?" In A. L. Epstein, R. S. Parker \& M. Reay (Eds.), The Politics of Dependence; Papua New Guinea 1968 (pp. 162-217). Canberra: ANU.

23. Harding, T. (1967). "A History of Cargoism in Sio, North-east New Guinea". Oceania, 38(1): 1-23.

24. Hjørland, B. 2106. "Informetrics needs a Foundation in the Theory of Science". In C. Sugimoto (Ed.), Theories of Informetrics and Scholarly Communication (pp. 28-41). Berlin: De Gruyter.

25. Höltker, G. (1946) "Schwarmgeister in Neuguinea während des letzten Krieges". Neue Zeitschrift für Missionswissenschaft, 2(3), 201-26.

26. Hudson, K. (1983) The Archaeology of the Consumer Society: The Archaeology of the Consumer Society. Teaneck, NJ : Fairleigh Dickinson University Press.

27. Hviding, E. (2011)“'Re-placing the State in the
Solomon Islands". In E. Hviding \& K.M. Rio (Eds.), Made in Oceania (pp. 51-89). Wantage, UK: Sean Kingston.

28. Jarvie, I. C. (1964) The Revolution in Anthropology. Chicago: University of Chicago Press.

29. Kallen, H. ([1936]) 2006) The Decline and Rise of the Consumer: A Philosophy of Consumer Coöperation. New York: Appleton-Century.

30. Kamma, F. (1972) Koreri: Messianic Movements in the Biak-Numfor Culture Area (Koninklijk Instituut voor Land-, Taal en Volkenkunde, Translation Series 15). The Hague: KILTV.

31. Keck, N. (1982) 'Melanesische Kultbewegungen als religios-ethnologisches Phänomen und Problem einer verstehenden Ethnologie: Die Cargo-Erwartung als Sinnerfüllung täglicher Müksal' (Doctoral dissert., University of Frankfurt am Main). Frankfurt am Main.

32. Kempf, W. (1996) Das Innere des Äussern: Ritual, Macht und historische Praxis bei den Ngaing in Papua Neuguinea. Berlin: Reimer.

33. Kirksey, E. (2012) Freedom in Entangled Worlds. Durham, NC: Duke University Press.

34. Knauft, B. (1978) "Cargo Cults and Relational Separation”. Behavior Science Research, 13(3). 185-240.

35. Landes, R. (2011) Heaven on Earth: The Varieties of Millennial Experience. Oxford, Oxford University Press.

36. Laracy, H. (1983) Pacific Protest: Maasina Rule, Solomon Islands. Suva: Institute for Pacific Studies.

37. Lattas, A. (2010) Dreams, Madness, and Fairy Tales in New Britain (Carolina Press Ritual Studies Monographs). Durham, NC: Carolina Academic Press.

38. Lawrence, P. (1964) Road belong Cargo: A Study of the Cargo Movement in the Southern Madang District, New Guinea. Manchester: Manchester University Press.

39. Lawrence, P. (1966-7) "Cargo Thinking as a Future Political Force in Papua and New Guinea". Journal of the Papua and New Guinea Society, 1(1), 20-25.

40. Lindstrom, L. ([1993] 2019) Cargo Cult: Strange Stories of Desire from Melanesia and Beyond. Honolulu, University of Hawaii Press.

41. Lindstrom, L. (1990) Knowledge and Power in a South Pacific Society. Washington, DC: Smithsonian Institution. 
42. Lloyd, C. (1993) Structures of History. Oxford: Basil Blackwell.

43. Loeliger, C. E., \& Trompf, G. W. (Eds.). (1985) New Religious Movements in Melanesia. Port Moresby: UPNG Press.

44. Mair, L. (1948) Australia in New Guinea. London, Christophers.

45. Mantovani, E. (1977) "A Fundamental Melanesian Religion”. Point, (1-2), 154-65.

46. Marx. K. ([1887] 1965) Capital (ed. F. Engels, and Eng. trans.). New York: International), vol. 1.

47. May, R.J. (Ed.).(1982) Micronationalist Movements in Papua New Guinea (Political and Social Change Monographs 1). Canberra: ANU Press.

48. McCarraher, E. ((2019) The Enchantments of Modernity: How Capitalism became the Religion of Modernity (Boston: Belknap).

49. Morauta, L. (1974) Beyond the Village: Local Politics in Madang (London School of Economics Monographs on Social Anthropology 49). London: Althone.

50. Moreton, B. (2009) To Serve God and WalMart: The Making of Christian Free Enterprise. Boston: Harvard University Press.

51. Nedopil, C. (2021) Countries of the Belt and Road Initiative. Beijing: IIGF Green BRI Centers. (online: www.green-bri.org)

52. Otto, T.(2009) "What Happened to Cargo Cults? Material Religions in Melanesia and the West". Social Analysis, 53(1), 82-102.

53. Patterson, M., \&Macintyre, M.(Eds.).(2014) Managing Modernity in the Western Pacific. Brisbane: University of Queensland Press.

54. Redding, G., \& Wong, G.(1986) "The Psychology of Chinese Organizational Behaviour". In M. Bond (Ed.). The Psychology of the Chinese People (pp. 289-95). Oxford: Oxford University Press).

55. Rimoldi, M. \& E. (1992) Hahalis and the Labour of Love: A Social Movement on Buka Island (Explorations in Anthropology). Oxford: Berg.

56. Salisbury, R. (1958) "An 'Indigenous' New Guinea Cult”. Kroeber Anthropological Papers, 128, 67-78.

57. Schor, J., \& Holt, D. (Eds.). (2000) The Consumer Society: A Reader (New York: New Press).

58. Schwartz, T. (1962) The Paliau Movement in the Admirality Islands, 1946-1954 (Anthropological Papers of the American Museum of Natural
History 49/20) (pp. 211-421). New York: AMNH;

59. Siikala, J. (1979) "The Cargo Proper in Cargo Cults". Temenos 15, 68-80.

60. Sillitoe, P. (2000) Social Change in Melanesia: Development and History. Cambridge: Cambridge University Press, p. 186;

61. Stephen, M. (1979) "Dreams of Change: The Innovative Role of Altered States of Consciousness in Traditional Melanesian Religion". Oceania, 50(1), 3-22.

62. Strathern, A. J. (1991) "Fertility and Salvation: The Conflict between Spirit Cult and Christian Sect in Mount Hagen", Journal of Ritual Studies, 5(1), 51-64.

63. Strelan, J. (1977) Search for Salvation. Adelaide, Lutheran Publishing House.

64. Stuart, A. (2009) Of Cargoes, Colonies and Kings: Diplomatic and Administrative Service from Africa to the Pacific. London: Radcliffe.

65. Sullivan, N. (2005) "Cargo and Condescension". Contemporary PNG Studies, 3, 31-46.

66. Swain, T., \& Trompf, G. W. (1995) The Religions of Oceania (Library of Religious Beliefs and Practices). London: Routledge.

67. Talmon, Y. (1966) "Millenarian Movements". Archives Européennes de Sociologie, 7(2), 159-200.

68. Taussig, M. (2010) The Devil and Commodity Fetishism in South America. Chapel Hill: University of North Carolina Press.

69. Tawney, R. H. ([1920] 2018) The Acquisitive Society. Sacramento, CA: Creative Media Partners.

70. Trompf "Cargo Cults". In A. Possamai \& A. Blasi (Eds.), The Sage Encyclopedia of the Sociology of Religion (vol. 1, pp. 109-110). Thousand Oaks, CA: Sage.

71. Trompf "Pacific Millennial Movements". In C. Wessinger (Ed.), The Oxford Handbook of Millennialism (pp. 435-54). Oxford: Oxford University Press.

72. Trompf, G. W. ([1998] 2019). Zong jiao qi yaun suo (trans. Z. Daiqing). Chengdu: Sichuan Peoples Publishing House.

73. Trompf, G. W. (1979) "Interpreting the Melanesian World-View; Man Facing Death and After-Life in Melanesia". In N. Habel (Ed.), Powers, Plumes and Piglets; phenomena of Melanesian Religion (pp. 121-136). Adelaide: AASR.

74. Trompf, G. W. (1987) "God as the Source of 
Wealth". Melanesian Journal of Theology. 3(1), 74-84.

75. Trompf, G. W. (1989) “Doesn't Colonialism Make You Mad? The so-called 'Mur Madness' as an Index to the Study of New Religious Movements in Papua New Guinea". In S. Latukefu (Ed.), Papua New Guinea: A Century of Colonial Impact 1884-1984 (p. 262). Port Moresby: UPNG Press.

76. Trompf, G. W. (1990)“Introduction”. In G. W. Trompf (Ed.), Cargo Cults and Millenarian Movements, (Religion and Society 29) (pp. 1-14).Berlin: Mouton de Gruyter.

77. Trompf, G. W. (1990) "The Cargo and the Millennium on Both Sides of the Pacific". In G. W. Trompf (Ed.), Cargo Cults and Millenarian Movements, (Religion and Society 29) (pp. 1215, 58-64).Berlin: Mouton de Gruyter;

78. Trompf, G. W. (1993) "Problems and Prospects of the World's Religions in Connection with the Environmental Future". InN. Polunin and J. Burnett (Eds.), Surviving with the Biosphere (Proceedings of the Fourth International Conference on Environmental Future [ $4^{\text {th }}$ ICEF], held in Budapest, Hungary, during 22-27 April 1990) (pp. 421-4). Edinburgh: Edinburgh University Press.

79. Trompf, G. W. (2004. "On Wondering about Wonder: Melanesians and the Cargo". In J. Olupona (Ed.), Beyond Primitivism (pp. 297313). London: Routledge.

80. Trompf, G. W. (2004) Melanesian Religion. Cambridge, Cambridge University Press.

81. Trompf, G. W. (2006) Religions of Melanesia: A Bibliographic Survey (Bibliographies and
Indexes in Religious Studies 57). London: Praeger.

82. Trompf, G. W. (2008) Payback: The Logic of Retribution in Melanesian Religions. Cambridge, Cambridge University Press.

83. Trompf, G. W. (2022) Violence and Religion Change in the Pacific (Elements in Religion and Violence). Cambridge: Cambridge University Press

84. Trompf, G.W. (2020) "About Cargo and the Melanesians". In Jennifer Reid (Ed.), This Root around my Person: Charles H. Long and New Directions in the Study of Religion (pp. 90-115). Albuquerque: University of New Mexico Press.

85. Wendling, A. 2009. Karl Marx on Technology and Alienation. New York: Palgrave Macmillan.

86. Wesley-Smith, T., \& Porter, E. (2010) China in Oceania: Reshaping the Pacific? (Foundations in Asia Pacific Studies 1). New York: Berghahn.

87. Whitehouse, H. (1991) "Cargoism, Millennialism, and Idealism". The Cambridge Journal of Anthropology, 15(1), 70-84.

88. Wiessner, P., \& Tumu, A. (2001) "Averting the Bush Fire Day: Ain's Cult Revisited”. In E. Messer \& M. Lambek (Eds.), Ecology and the Sacred: Engaging the Anthropology of Roy A. Rappaport (pp. 300-23). Ann Arbor: University of Michigan Press.

89. Worsley, P. ([1957] 1970) The Trumpet Shall Sound: A Study of "Cargo" Cults in Melanesia. London, Paladin.

90. Worsley, P. (2006) "Paliau Maloat." In P. Clarke (Ed.), Encyclopedia of New Religious Movements, ed. Peter Clarke (pp. 438-40). New York: Routledge. 